\title{
Hommage à la Police (in nummis)!
}

\section{VÁJLOK Lászlón ${ }^{1}$}

\begin{abstract}
Hódolat a rendészetnek! - mondhatnánk, és ünnepelhetjük a rendészetet érintő megannyi kerek évfordulót. Az évforduló hangos vagy éppen csendes megünneplése során jusson eszünkbe, hogy egy rendészeti vagy rendészeti jellegü feladatot ellátó szervezet az idők során mennyire vívta ki a társadalom, a civilek, a polgárok megbecsülését. Mennyit tettünk és tettek mások azért, hogy elismerjék szervezetünket, és ennek milyen - szó szerint - kézzelfogható, mindennapokban tetten érhetö módja van. E rövid kis írás a történelemtudomány egyik segédtudományán keresztül kívánja rendhagyó módon ezt bemutatni.
\end{abstract}

Kulcsszavak: rendészet, rendészeti szervek, megbecsülés

2020-ban ünnepeljük a modern (állami) rendőrség születésének centenáriumát (bár a rendőrség államosításáról szóló 5047/1919 (X. 1.) ME r. alapján már 1919. október 1-jétől egységes állami rendőrségről beszélhetünk, a rendeletben foglaltakat az 1920. évi I. törvénycikk, 1920. február 29-én léptette hatályba). Számtalan szakmai és társadalmi program, kiadvány mutatja be az elmúlt 100 évet, tisztelegve a szervezet elmúlt időszakának. Ha a rendőrség helyett a rendészetre koncentrálunk, ez az év több évfordulót is tartogat számunkra, amelyekrôl vagy van tudomásunk, vagy nincs, de az adott rendészet vagy „rendészettípusú” szervezetnek mindenképpen ünneplésre adhat okot. Itt van például a Magyar Országos Túzoltó Szövetség megalakulásának 150. évfordulója, amely időszak egyben a magyar hivatásos tủzoltóság megalakulásának is ugyanezen évfordulója, vagy akár megemlékezhetünk a Magyar Királyi Csendőrség idén 80 éves légi szolgálatáról is. ${ }^{2} \mathrm{~A}$ történelemben az a szép, hogy szinte minden évszámhoz kapcsolható olyan esemény, amely egy adott szakma képviselői számára sokat jelent. És hogy a fentieken kívül csak néhányat említsek a teljesség igénye nélkül (elsősorban a rendészettel összefüggésben említve) ez évben:

- 20 éves az egységes hivatásos katasztrófavédelmi szervezet;

- 30 éves az Alkotmányvédelmi Hivatal demokratikus jogelődje (a Nemzetbiztonsági Hivatal);

- 30 éve kezdődött a hivatásos határőrizeti rendszer kiépítése;

- 50 éve született döntés a Rendőrtiszti Főiskola létrehozásáról;

Vájlok László r. alezredes, Nemzeti Közszolgálati Egyetem Rendészettudományi Kar Határrendészeti Tanszék, referens.

László Vájlok pol. lieutant colonel, University of Public Service Faculty of Law Enforcement Department of Border Police, referent.

E-mail: Vajlok.Laszlo@uni-nke.hu, ORCID: https://orcid.org/0000-0003-4255-5808

2 Som Krisztián: A magyarországi légi határforgalom és ellenörzése I. kötet. Budapest, Magánkiadás, 2020. 9. 
- 70 éve alakult meg az Országos Pénzügyőri Főparancsnokság;

- 70 éve vált ki a határőrség a honvédség szervezetéből, és került a Belügyminisztérium szervezetébe, továbbá rá öt évvel, azaz 65 éve alakult meg a határőrség;

- 75 éve alakult meg a modernkori pénzügyőrség (1945-ben törölték el a „királyi” jelzőt);

- 180 éve hozták létre a mezei rendőrséget;

- 190 éve volt a Ludovika Akadémia alapkőletétel;

és a sort folytathatnánk...

Visszatérve a korábban említett egyik jelentős eseményre, a hivatásos tûzoltóság megalakulásának 150. évfordulójára, egy rendkívül kedves gesztus a Magyar Nemzeti Bank (MNB) részéről, hogy a polgárok millióihoz eljutó legegyszerúbb eszközzel, egy pénzérmével öregbítik a szervezet - egyébiránt a társadalmilag legelfogadottabb szervezet - hírnevét. A példát tekintve felmerült a kérdés, hogy korábban erre volt-e gyakorlat hazánkban vagy esetleg más országok esetében mennyire veszik komolyan a rendészeti szervek társadalmi „reklámját” pontosan e módszer segítségével. Hiszen valljuk be, egy forgalmi pénzérme kétmilliós tételű kibocsátásával bizony nagyon sok emberhez el lehet juttatni a szervezet hírét még akkor is, ha ezek a fajta érmék a gyüjtői szenvedélynek köszönhetően viszonylag relatíve gyorsan ki is kopnak a forgalomból.

A történelemtudománynak létezik (a sok mellett) egy segédtudománya, amely kifejezetten a pénzt és annak történetét kutatja, ez pedig a sokak által ismert numizmatika. A numizmatika természetesen sokkal tágabb kutatási területet ölel fel, mint maga a pénzérme megjelenítése és „reklámhordozó” mivolta. Ráadásul számtalan más segédtudomány is létezik, amely a rendészet területén is megvetette lábait, mint például a heraldika (szervezetek címerei), vexillológia (szervezetek zászlói) esetleg a falerisztika (érdemjelek, kitüntetések) vagy éppen a legjelentősebb hobbitevékenység, a filatélia (bélyegek), amely két utóbbi szinte teljesen ki is sajátította a rendészet, rendvédelem, honvédelem szervezeteinek „népszerűsítését”.

Elmondható, hogy míg a rendészeti szervekről „megemlékező” emlékplakett, emlékérem, zászló, kitüntetés számtalan formában elérhető és látható a tematika iránt érdeklődők számára, addig a nagyközönséghez is egyszerűen eljuttatható forgalmi pénzérme emlékváltozata már korántsem ilyen eszköz. Ennek természetesen az az észszerű magyarázata, hogy eléggé korlátozott szabályai vannak a forgalmi pénzek éremképeinek változtatására mind Magyarországon, mind az euróövezet országaiban, mind pedig más országokban.

Hogy mégis múködhet (múködik) ez a fajta társadalmi „ismeretterjesztés”, arra - alapvetően - a forgalmi pénzérmék emlékváltozatain keresztül kívánok rávilágítani, szigorúan maradva a rendészeti (vagy azzal egyenértékű közigazgatási/ hatósági) tevékenységet ellátó szervekre összpontosítva. Mielőtt a konkrétumokat is számba vennénk, érdemes megjegyezni, hogy különbséget kell tenni az emlékérem, az érem és a nem forgalmi célú emlékérme között, amelyeket ráadásul teljesen el kell 
határolni a kifejezetten forgalmi pénzérmék „ideiglenes” vagy más kifejezéssel élve, jubileumi változataitól. Egy egyszerű példánál maradva ezen utóbbi körébe tartozik az új 50 forintos („tűzoltós”) pénzérménk, amely hasonló értékközvetítést jelez, mint a korábban mindenki számára ismert FINA (Nemzetközi Úszószövetség) Világbajnokság évében kétmillió példányban kiadott 50, vagy a birkózó világbajnokság apropójából 2018-ban vert és kétmillió példányban kiadott 50 forintosunk. Idesorolható továbbá a Kossuth Lajos születésének 200. évfordulója alkalmából 2002-ben vert bimetál 100 forintos érménk vagy a Deák Ferenc portrét tartalmazó 2003-as 20 forintos is. Ezen konkrét fizetőeszközökhöz képest az előzőekben felsoroltak viszont csak korlátozottan rendelkeznek „fizetőképességgel”.

Számtalan olyan pénznek tűnő veret is található, amelyről hiányoznak a forgalmi pénzekkel szemben támasztott kötelezően meghatározott elemek, mint például a névérték, a kibocsátó, az évszám, esetleg a verdejel. Az is kétségtelen, hogy a rendészetet érintő megjelenés tekintetében ezek között van a legtöbb, hiszen például a Nemzeti Közszolgálati Egyetem is rendelkezik emlékérmével (Aranyérme és Egyetemért Emlékérem), amely adományozható, viszont éppen adományozható jellege miatt nem juthat el sokakhoz, azaz zártkörú ajándék. Végül a teljesség kedvéért röviden meg kell jegyezni, hogy az emlékplakettek főleg nem tartoznak jelen írás céljai közé, noha pont ezek között találhatunk sok rendészeti vagy hadtörténeti kapcsolatot felmutató kuriózumot. A széles körű spektrum tényleg szó szerint értelmezendő, hiszen nemcsak az adott rendészeti vagy katonai szervezetről (rendőrség, határőrség,) vagy az ahhoz kapcsolódó személyről (Kertész Imre, Görgey Artúr), hanem az azokhoz kapcsolható egyéb intézményekről (Rendőrtiszti Főiskola, rendészettudományi társaság, kórház) is jelentek meg érem- vagy plakettkiadások. Egy szemléletes példája a Büntetés-végrehajtás Központi Kórházról 1986-ban készült plakett, amely egyrészről a büntetésvégrehajtási szervezetet is szimbolizálja, másrészről az orvostudomány, orvoslás sokszínűségét is kifejezi. ${ }^{3}$

A konkrét példák áttekintése során elsőként a hazai kibocsátást illik számba venni. A 2020. május 4-ére (Szent-Flórián, a tǔzoltók védőszentjének napjára) időzített 50 forintos pénzérme emlékváltozatát két másik, forgalmi értékkel felruházott emlékérme is kísérte, egy 2000 forintos és egy 10000 forintos, előlapján a tűzoltóság jelmondatát („Dicső múltból a méltó jövőbe”), tűzoltósisakot és bontóbaltákat, valamint hátoldalán a „150 éves a szervezett magyar tűzoltóság” feliratot és Szent Flóriánt ábrázoló réznikkel és ezüst érme. Az érmekép egyébként a hagyományokra utalva szinte teljes egészében megegyezik az első hivatalos szolgálati érem vésetével, amely már 1886-tól díszítette a „Magyar Országos Tüzoltó Szövetség” köriratú veretet. ${ }^{4}$

Az 50 forintos emlékérméből (1. ábra) 2 millió darab jut el a lakossághoz ez évben, így valójában elmondható róla, hogy népszerủsíti és tovább növeli a tûzoltók népszerűségét és megbecsülését. Egyébiránt viszonylag ritkának mondható, hogy

\footnotetext{
Csoma Mária: Medicina in nummis - Magyar orvosi érmek katalógusa 1974-1994. Budapest, Semmelweis Orvostörténeti Múzeum, Könyvtár és Levéltár, 2000. CXVII. tábla.

4 Pataki Ferenc: Adatok a tűzoltó érmék készülő katalógusához I. Az Érem, 36. (1980), 1. 39.
} 
kétféle emlékérme mellett forgalmi érme emlékváltozatát is kibocsátják egyidejűleg, ez azonban mindenképpen a szakma elismertségét mutatja. A tűzoltók nemzetközi téren is magas presztízsét mutatja, hogy forgalmi érme emlékváltozata tekintetében több ország is választotta, választja érmeverés témájául saját nemzeti tûzoltóságát.

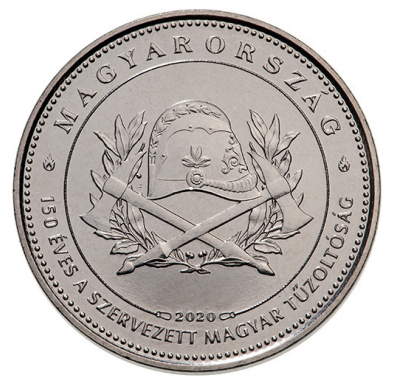

1. ábra: Magyar Nemzeti Bank - 50 forint emlékváltozat. Forrás: Magyar Nemzeti Bank:

Forint érmék emlék változatai. é. $n$.

Hazai színtéren maradva még egy érméről lehet (és érdemes) beszámolni, természetesen az is a tűzoltókhoz kapcsolódik, mégpedig Szilvay Kornél egykori budapesti tűzoltóparancsnok („a szárazoltás atyja”) születésének 125. évfordulója alkalmából a portréját ábrázoló (2. ábra) és az általa 1927-ben megalkotott szárazoltó járműről 2015-ben kiadott 2000 forintos rézötvözetű négyszögleges veretről (3. ábra). Az érmét mintegy 10 ezer példányban verték (megosztva a tükörfényes és a selyemfényes veret), előlapján a feltaláló, míg hátoldalán a névérték, alatta maga az oltógép látható. Fontos megjegyezni, hogy ez az érem nem forgalmi érme emlékváltozata, tehát jelen írás célját tekintve csak annyiban említem meg, mint a rendkívül kevés rendészeti témájú és forgalmi értékkel rendelkező pénzérméink egyikét.

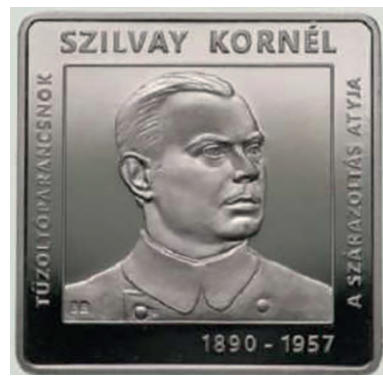

2. ábra: Magyar Nemzeti Bank - Emlékérme Szilvay Kornél születésének 125. évfordulójára - Av. Forrás: Magyar Nemzeti Bank: Emlékérme Szilvay Kornél születésének 125. évfordulójára. 2015. 


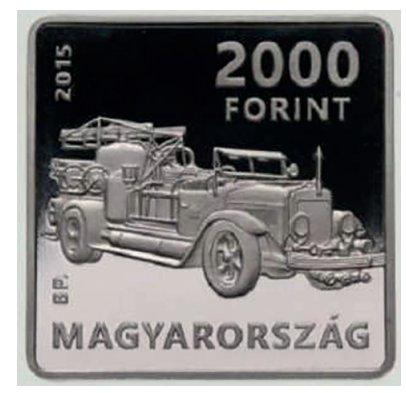

3. ábra: Emlékérme Szilvay Kornél születésének 125. évfordulójára - Rev. Forrás: Magyar Nemzeti Bank (2015) i. m.

Sajnálatos módon a rendészeti témájú hazai érmeveretek számbavétele itt be is fejeződik, ugyanakkor az alábbiakban néhány további, más országbeli veretek bemutatásával jól illusztrálható az a tisztelet, amit egy adott ország a saját szervei iránt mutat.

$\mathrm{Az}$ ismertetés során az anyag terjedelmére tekintettel alapvetően az Európában (azon belül is az Európai Unióban) vert, rendészeti tartalmú érméket kívánom bemutatni. Az európai érméket két részre bontva lehet vizsgálni, egyrészről a már nem forgalomban lévő érméket (például az euró előtt forgalomban volt nemzeti pénzeket), és a jelenleg is forgalomban lévő (alapvetően az euró-) érméket, amely utóbbiak több érdekességgel is szolgálnak. Jelen írás további része kifejezetten ez utóbbiakat veszi górcső alá.

$\mathrm{Az}$ euróérmékkel kapcsolatban általában mindenki tisztában van azzal, hogy egy-egy euróövezeti tagállam a nyolc különféle érméinek egyik oldalát saját nemzeti jelképrendszerével ékesíti, míg a másik oldal (az írás) formája kötött, amint azt egyébként az Európai Unió Tanácsa meghatározza. A szabványos érmék nemzeti elólapja alapvetően 15 évenként egyszer változtatható meg, kivéve, ha az azon feltüntetett államfő személye megváltozik (vonatkozik ez arra is, hogy lekövessék az államfő külsőjének változását is). Ez alól kivételt kizárólag a legnagyobb címletű érme, a kéteurós képez, ezek egyik (nemzeti) oldalát ugyanis évente egyszer (kivételes esetben kétszer) egy-egy jeles eseményhez kötötten, ideiglenesen és csak meghatározott példányszámban meg lehet változtatni, hasonlóan, mint hazánkban az 50 forintos érmék fejoldalát. Az ilyen változtatást természetesen az Európai Unió Hivatalos Lapjában (EUR-Lex) ki is kell hirdetni. Jelenleg megközelítőleg 450 féle kéteurós érmeváltozat van (lehet) forgalomban, mindegyik változat egy-egy tagállam jeles eseményéhez, személyéhez, nemzeti értékéhez vagy szimbólumához (ahogy mi mondanánk „hungarikumhoz"), esetleg szervezetéhez köthetően.

Ez utóbbihoz sorolható szám szerint hatféle olyan kéteurós érme, amelyek éremképe kapcsolódik a rendészethez. Ezek közül kettő olasz, egy-egy pedig máltai, monacói, portugál, illetve vatikáni kiadás. 
Olaszország igazán példát tud mutatni mind a mai napig a nálunk szolgáló szervezetek megbecsültségének és imázsnövelésének. Számtalan példáját láthatjuk az olasz televíziók valamelyik csatornáján fő műsoridőben a díszegyenruhában nyilatkozó, vagy egy-egy szomorú esemény során készült felvételeken az ott dolgozó és szolgálatot ellátó rendészeti szervek (például földrengések alkalmával a polgári védelem) hangsúlyos megjelenítésének. Ezért nem is csodálkozunk, hogy már a líra pénzrendszer korszakában is több olyan forgalmi érme emlékváltozata látott napvilágot, amely egy-egy rendészeti szervhez köthető, így létezik 200 lírás forgalmi pénz emlékváltozata a 180 éves csendőrségről, a csendőrség 30 éves múvészeti örökségvédelmi munkájáról és a 100 éves olasz vámakadémiáról, de például 500 lírás emlékváltozatot kapott az akkor 50 éves közlekedésrendészet is.

$\mathrm{Az}$ olasz kéteurós érme közül az egyik az idén éppen 80. évét ünneplő olasz nemzeti tűzoltóságnak, a Corpo Nazionale dei Vigili del Fuoco-nak állít maradandó emléket. Az érme változtatható oldalán a nemzeti tűzoltóság logója látható (4. ábra), a szervezet nevével fémjelezve. Természetesen a biztonság (hamisítás megelőzése) és a „pénz” jellegének megőrzése érdekében a kötelező egyéb elemek, mint a verdejel, évszám, esetleg a tervezőre utaló jegyek is megtalálhatók, illetve sem anyagában, sem rétegében (bimetál és háromrétegü), azaz technikai jellemzőiben sem térhet el az ilyen érme a tömeges nemzeti kéteurós érmék tulajdonságaitól, és ez igaz az összes euróövezeti tagállam által kiadott emlékváltozatra. Az érméből 3 millió darabot bocsátottak ki 2020. januári kezdettel.

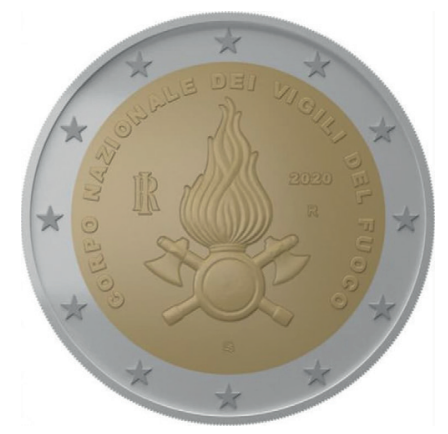

4. ábra: Euró forgalmi emlékérme az olasz tüzoltók tiszteletére. Forrás: Poligrafico e Zecca della Stato Italiano: 2 euro Vigili del Fuoco. é. $n$.

Olaszország másik hasonló témájú emlékverete az olasz Csendőrség, az Arma dei Carabinieri alapításának 200. évfordulójára kiadott változata, amelyet 2014 júniusában 6,5 millió darabban bocsátottak ki. Az érmeképen (5. ábra) Antonio Berti szobrászművész által készített szoborról mintázott veretmásolat látható, és a „Pattuglia de Carabinieri nella tormenta" (Csendőrjárőr a hóviharban) címet viseli, eredetiben pedig Rómában, a Sant'Andrea al Quirinale Kertben látható. 


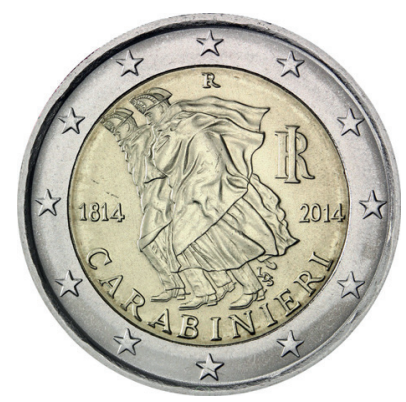

5. ábra: Euró forgalmi emlékérme az olasz csendőrség tiszteletére. Forrás: Fleur de Coin: Italy 2 euros $2014-200^{\circ}$ Anniversary of the Carabinieri.

Portugália 520 ezer példányszámban 2017-ben bocsátotta ki a 150 éves közbiztonságnak emléket állító kéteurós érméit. A viszonylag alacsony példányszámból 10-10 ezret színes, illetve tükörveret változatban is kibocsátottak (utóbbit szinte kizárólag csak a gyűjtők számára). Az emberi fejek és a házak az állampolgárokat és a városokat szimbolizálják, mint a rendészet megszületésének sine qua non-ja. A portugál feliratok egyrészről a „közbiztonság” (Segurança Pública), másrészről az állampolgársághoz kapcsolódó három legfontosabb alapelv „jogok” (Direitos), „szabadságok” (Liberdades) és „garanciák” (Garantias) kifejezéseket jelenítik meg (6. ábra). A feliratok között pedig az 1867-2017 évszámok is szerepelnek, amelyek a portugál (közbiztonsági) rendőrség (Polícia Seguranca Pública) megalakulásának és az érmekibocsátás éveire utalnak.

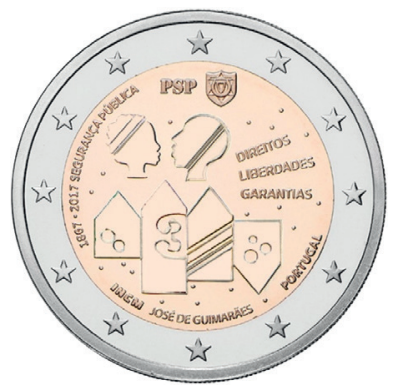

6. ábra: Euró forgalmi emlékérme a rendészet tiszteletére. Forrás: Fleur de Coin: Portugal 2 euros 2017 - 150 Years of the Police and Public Security.

Málta, a maga viszonylag csekély mennyiségú pénzkibocsátásához képest jelentős mértékben él az egyedi forgalmi emlékpénz-változatok kibocsátásával. Ez évig mintegy 39 különféle kéteurós érmeváltozatot veretett, ezzel megelőzve olyan nagy országokat, mint Portugália, Olaszország vagy Spanyolország. A 39 emlékváltozat között nem csoda, hogy megfér egy számunkra ritkaság is, mégpedig a Máltai Rendörség 
fennállásának bicentenáriuma alkalmából kibocsátott veret, amely 300 ezer példányban készült 2014-ben (7. ábra).

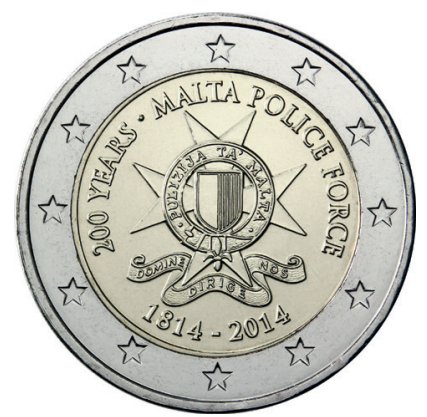

7. ábra: Euró forgalmi emlékérme a máltai rendörök tiszteletére. Forrás: Fleur de Coin: Malta 2 euros 2014 - 200 th Anniversary of the Malta Police Force.

A kis szigetország rendőrsége az egyik legrégebbi ilyen szervezet Európában, létrehozására 1814-ben került sor. Az érmeképen a „200 éves a Máltai Rendőrség” felirat és az évszám: „1814-2014” szerepel.

Ha már kis országok (államok) is szóba kerültek, meg kell említeni a Vatikán város különleges pénzveréséhez kapcsolódó kéteurós forgalmi emlékkiadását is, mégpedig hasonlóan Máltához, itt is egy 200 éves évfordulónak állítanak emléket. Ez pedig nem más, mint a 2016 júniusában a vatikánvárosi csendőrség, azaz a Corpo della Gendarmeria iránti tiszteletből veretett 105 ezer darabos érme (8. ábra). A csendőrség nem tévesztendő össze a római pápa testőrségét is ellátó katonai alakulattal, amely leginkább színes-csíkos díszegyenruhájáról jut eszébe az embereknek. A csendőrség a megszokott sötét-/világoskék egyenruhában és az elmaradhatatlan kepiben (cappello) látható vatikáni sétáink során.

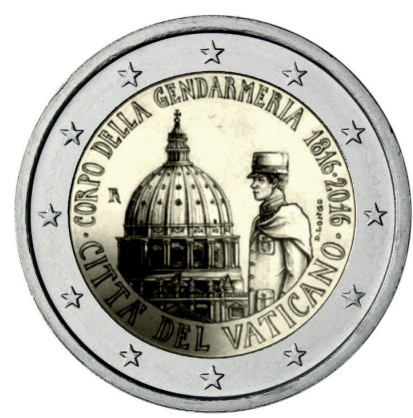

8. ábra: Euró forgalmi emlékérme a vatikáni csendőrség tiszteletére. Forrás: Fleur de Coin: Vatican 2 euros 2016 - Corps of G endarmerie. 
A Monacói Hercegség is élt az emlékváltozat kibocsátásának lehetőségével, amikor 2017. november 13-ával 15 ezer darabos kéteurós emlékérmét vert forgalmi pénzként a monacói, pontosabban a „hercegi” csendőrség (Carabiniers du Prince) 200 éves fennállásának emlékére. Az érme változtatható képén a monacói palota előterében két csendőr alakja látható, távolabbi korabeli (1817) egyenruhában, míg az előtérben tisztelgő csendőr már a szervezet modern egyenruháját viseli (9. ábra). Az érmekép felirata „Monaco”, illetve „Carabiniers du Prince”, valamint az évszám: 1827-2017.

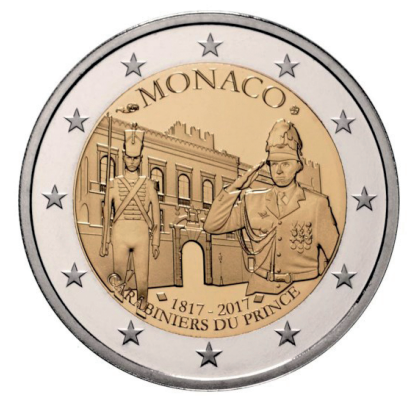

9. ábra: Euró forgalmi emlékérme a monacói csendőrség tiszteletére. Forrás: Royal Dutch Mint: Monaco 2 Euro “Carabiniers" 2017 Proof.

Az euróérmék számbavétele után egyetlen rövid példa más európai uniós ország (ez esetben Lengyelország) korábbi pénzverésére. A példa bemutatásának oka egyéni indíttatású, hiszen egy nem is teljesen kerek évfordulóhoz kapcsolódóan jelent meg erőteljes szimbolikával a magyar rendőrséghez hasonló européer szervezet.

Lengyelország mintegy 760 ezer példányszámban bocsátotta ki 2004-ben az akkor 85. (!) évét ünneplő rendőrség iránti tiszteletből a két zlotys érme emlékváltozatát. $\mathrm{Az}$ érme egyik oldala, hasonlóan az általános forgalmi érméhez, a lengyel címer, azonban másik oldala (a hátlap) a rendőrség címerének, illetve a „85. Rocznica Powołania Policji” (Rendőrség alapításának 85. évfordulója) felirat vésetét viselte (10. ábra).

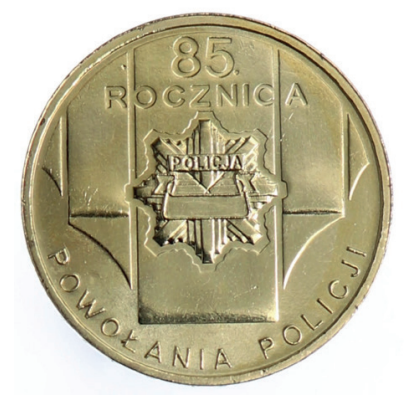

10. ábra: Forgalmi emlékérme a lengyel rendörség tiszteletére. Forrás: www.nbp.pl/homen. aspx?f=/en/banknoty/kolekcjonerskie/2004.html\#08 
Természetesen a világ más részei is adóznak a rendészeti szerveknek tisztelettel forgalmi pénzérmék útján, hiszen több olyan forgalmi célú emlékverettel is találkozunk szinte minden földrészről, amelyek a rendészeti szerveknek, elsősorban a rendőrségnek vagy a csendőrségnek állítanak emléket. Így érdekességként és csak megemlítés szintjén, a teljesség igénye nélkül példaként említem az alábbi országokat:

- Belorusszia a 100 éves Állami Határőrségről és a 100 éves Állami Rendőrségről kiadott 1-1 rubeles;

- Egyesült Arab Emírség az 50 éves Dubai Rendőrség, illetve az 50 és 60 éves Abu-Dhabi rendőrségének emlékére kiadott 1-1 dirham;

- Malajzia 2007-ben a malajziai rendőrség bicentenáriumára kiadott 1 ringgit;

- Kanada jelenleg is forgalomban lévő 25 centese a Kanadai Lovasrendőrség (Royal Mountain Police) fennállásának 100. évéről, vagy ugyanezen testület 125 . évfordulójára emlékezve 1998-ban kiadott 1 dollár;

- Egyiptom 1988-ban kiadott 5 fontosa az állami rendőrség napjáról (január 25);

- Ausztrália 2011-ben kiadott 50 centese, amely a „triple-zero”-nak, azaz a rendőrség, mentőszolgálat és tűzoltóság közös segélyhívószámának 50. évfordulójára emlékezik.

De természetesen lehetne még beszélni a nem forgalmi célú emlékveretekről is, hiszen erre akár Európában is több példát találhatunk, sőt egyik, az éremgyűjtők körében legismertebb ilyen darab éppen nyugati szomszédunkból, Ausztriából származik, amely az akkor 125 éves Osztrák Csendőrségnek állított emléket az 1974-ben kibocsátott 50 (ezüst) Schillinggel (11. ábra).
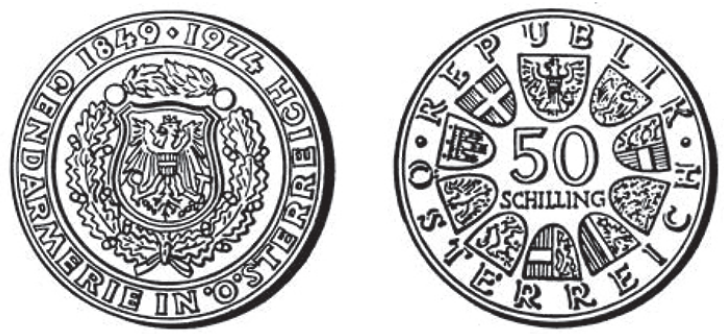

11. ábra: Színezüst forgalmi emlékérme az osztrák csendőrség tiszteletére. Forrás: Oesterreichische Nationalbank: Gesamtverzeichnis der Schillingmünzen von 1947 bis 2001. Wien, 2018. 17.

Állítható, hogy a közeljövőben forgalmi érméinken számottevően nem fogunk találkozni rendészeti tartalmú képekkel és információkkal, ugyanakkor más numizmatikai tárgyak (mint például az emlékplakettek) számtalan formában „hirdetik” a rendészetet. Éppen ezért volt kicsit fura, hogy az idén 100 éves rendőrség nem kapott (vagy nem kért?) lehetőséget az „önreklámra”. 
A rendészettörténet kutatóira vár az a nemes feladat is, hogy összegyújtsék az egyes szórványgyűjtemények darabjait, katalogizálva a rendészet területét felölelő érmek és érmék sokaságát. Nem egyedi kezdeményezés lenne, hiszen ahogy például a Szent-György érmeknek önálló katalógusa ${ }^{5}$ létezik, úgy megtalálható az orvosi pályával kapcsolatos gyüjtemények ${ }^{6}$ rendszerezése vagy a korai koronázási érmék gyưjteménye $^{7}$ is. Ráadásul pusztán csak a budapesti tűzoltómúzeum 3000 darabos (!) tǔzoltóérem-gyújteménye rendkívül gazdag és megfelelő alapot adhat egy „Politeia in nummis" kiadványhoz. E témában ugyan született már kezdeményezés ${ }^{8}-$ immár 40 éve (!) -, azonban végleges katalógus összeállítására tudomásom szerint még nem került sor.

\section{FELHASZNÁLT IRODALOM}

Csoma Mária: Medicina in nummis - Magyar orvosi érmek katalógusa 1974-1994. Budapest, Semmelweis Orvostörténeti Múzeum, Könyvtár és Levéltár, 2000.

Huszár Lajos: Szent György érmek. Budapest, Magyar Történeti Múzeum, 1940.

Pálffy Géza - Soltész Ferenc Gábor - Tóth Csaba: Coronatio Hungarica in nummis. A magyar uralkodók koronázási érmei és zsetonjai (1508-1916). Budapest, MTA Bölcsészettudományi Kutatóközpont, 2016.

Pataki Ferenc: Túzoltó szolgálati érmékről. Az Érem, 29. (1973), 1. 38-44.

Pataki Ferenc: Adatok a tűzoltó érmék készülő katalógusához I. Az Érem, 36. (1980), 1. 32-38.

Som Krisztián: A magyarországi légi határforgalom és ellenörzése I. kötet. Budapest, Magánkiadás, 2020.

Nemzeti Közszolgálati Egyetem: Nemzeti Közszolgálati Egyetem Arculati Kézikönyv. Online: www. uni-nke.hu/document/uni-nke-hu/egyetemi-arculati-kezikonyv_-hataly-2016_-ii_-1-tol.original.pdf

\section{Internetes források}

Fleur de Coin: Italy 2 euros $2014-200^{\circ}$ Anniversary of the Carabinieri. Online: www.fleur-de-coin. com/coin-shop/Italy-2-euros-2014-200\%C2\%B0-Anniversary-Carabinieri_eur17157

Fleur de Coin: Portugal 2 euros 2017 - 150 Years of the Police and Public Security. Online: www.fleurde-coin.com/coin-shop/Portugal-2-euros-2017-150-Years-Police-Public-Security_eur30594

Fleur de Coin: Malta 2 euros 2014 - 200 th Anniversary of the Malta Police Force. Online: www.fleur-decoin.com/coin-shop/Malta-2-euros-2014-200th-Anniversary-Malta-Police-Force_eur25197

Fleur de Coin: Vatican 2 euros 2016 - Corps of Gendarmerie. Online: www.fleur-de-coin.com/coinshop/Vatican-2-euros-2016-Corps-Gendarmerie_eur30493

Magyar Nemzeti Bank: Forint érmék emlék változatai. é. n. Online: www.mnb.hu/bankjegy-es-erme/ ermeink/forintermek-emlek-valtozatai

\footnotetext{
Huszár Lajos: Szent György érmek. Budapest, Magyar Történeti Múzeum, 1940.

Lásd a már hivatkozott Medicina in nummis-t.

Pálffy Géza - Soltész Ferenc Gábor - Tóth Csaba: Coronatio Hungarica in nummis. A magyar uralkodók koronázási érmei és zsetonjai (1508-1916). Budapest, MTA Bölcsészettudományi Kutatóközpont, 2016.

8 Pataki Ferenc: Túzoltó szolgálati érmékről. Az Érem, 29. (1973), 1. 33.
} 
Magyar Nemzeti Bank: Emlékérme Szilvay Kornél születésének 125. évfordulójára. 2015. Online: www.mnb.hu/bankjegy-es-erme/emlekermek/2015/emlekerme-szilvay-kornel-szuletesenek-125-evfordulojara

Oesterreichische Nationalbank: Gesamtverzeichnis der Schillingmünzen von 1947 bis 2001. Wien, 2018. Online: www.muenzeoesterreich.at/service/online/download-center

Poligrafico e Zecca della Stato Italiano: 2 euro Vigili del Fuoco. é. n. Online: www.shop.ipzs.it/2020moneta-vigili-del-fuoco-2e-fdc48-2ms10-20f008.html

Royal Dutch Mint: Monaco 2 Euro “Carabiniers" 2017 Proof. Online: www.royaldutchmint.com/monaco-2-euro-carabiniers-2017-proof/en/product/9660/\#/zoom

www.nbp.pl/homen.aspx?f=/en/banknoty/kolekcjonerskie/2004.html\#08

\section{ABSTRACT}

\section{Hommage à la Police (in nummis)!}

László VÁJLOK

"Homage to policing!" - we say every time we celebrate an anniversary in the life of law enforcement. Regardless we celebrate loudly or silently; we must remember how law enforcement and all other agencies that perform such functions have earned civilians', the public's, and our whole society's respect. We have gone great lengths for our organization to earn respect; and it is great to see how much - even tangible - results it has in our everyday lives. In this article we discuss this phenomenon from a specific point of view: through history and its auxiliary sciences.

Keywords: policing, law enforcement agencies, appreciation 